\title{
HIGH-TEMPERATURE PROCESSING AND RECOVERY OF AUTOCATALYSTS
}

\author{
VISOKOTEMPERATURNO PROCESIRANJE IN RECIKLAŽA \\ AVTOMOBILSKIH KATALIZATORJEV
}

\author{
Mária Čarnogurská ${ }^{1}$, Miroslav Př́íhoda ${ }^{2}$, Marián Lázár ${ }^{1}$, Peter Kurilla ${ }^{1}$, Romana Dobáková ${ }^{1}$ \\ ${ }^{1}$ Technical University of Košice, Faculty of Mechanical Engineering, Vysokoškolská 4, 04200 Košice, Slovakia \\ ${ }^{2}$ VŠB - Technical University of Ostrava, Faculty of Metallurgy and Materials Engineering, 70833 Ostrava -Poruba, Czech Republic \\ maria.carnogurska@tuke.sk
}

Prejem rokopisa - received: 2017-10-12; sprejem za objavo - accepted for publication: 2017-12-19

doi:10.17222/mit.2017.174

\begin{abstract}
This paper presents the results from an experimental study of the thermal method applied for obtaining platinum-group metals (PGMs) by melting used autocatalysts in an $80 \mathrm{kVA}$ plasma reactor, using suitable fluxes and a reducing agent. As the collector of noble metals, grey cast iron was used during the melting. The melt products were the alloy, inert vitrified slag, syngas and fly ash. In the alloy, when melting the catalyser based on cordierite, there was $99.27 \%$ PGMs and $99.00 \%$ in the case of $\mathrm{Cr} / \mathrm{Ni}$-strip catalysts. The loss of PGMs in the slag during the melting of cordierite catalysts was $0.34 \%$ and for Cr/Ni catalysts, it was $0.26 \%$. A chemical analysis of the ash confirmed that in addition to the mechanically removed $\mathrm{CaO}_{2} \mathrm{SiO}_{2}, \mathrm{MgO}_{2} \mathrm{Al}_{2} \mathrm{O}_{3}$, it also contained condensed vapours of Fe+PGMs. During the melting of the cordierite catalyst, the ash contained $0.40 \%$ of the refined metals, while $0.74 \%$ was the figure for the $\mathrm{Cr} / \mathrm{Ni}$-strip catalyst. The synthesis gas from the process had a very low heating value $\left(0.16 \mathrm{MJ} \mathrm{m}^{-3}\right.$ or $\left.0.24 \mathrm{MJ} \mathrm{m}^{-3}\right)$.
\end{abstract}

Keywords: waste, catalyser, platinum-group metals, plasma technology

V tem članku avtorji predstavljajo rezultate eksperimentalnih raziskav termičnega postopka pridobivanja kovin platinske skupine (PGM, angl.: Platinum Group Metals) s taljenjem izrabljenih avtomobilskih katalizatorjev v $80 \mathrm{kVA}$ plazemskem reaktorju $\mathrm{z}$ uporabo primernih talil in redukcijskega sredstva. Kot zbiralnik plemenitih kovin je bila med taljenjem uporabljena siva litina. Produkti taljenja so zlitina, inertna steklasta žlindra, sintezni plin in pepel. V zlitini je bilo pri taljenju katalizatorja na osnovi kordierita koncentriranih 99,27\% PGM, pri katalizatorjih s Cr/Ni trakom pa 99,00\%. Pri taljenju kordieritnih katalizatorjev se je $\mathrm{v}$ žlindri izgubilo $0,34 \% \mathrm{PGM}$, pri Cr/Ni katalizatorjih pa $0,26 \%$. Kemijska analiza pepela je potrdila, da poleg mehansko pridobljenih oksidov $\mathrm{CaO}, \mathrm{SiO}_{2}, \mathrm{MgO}, \mathrm{Al}_{2} \mathrm{O}_{3}$, le-ta vsebuje tudi kondenzirane pare $\mathrm{Fe}$ in PGM. V pepelu se je pri taljenju katalizatorja na osnovi kordierita nahajalo $0,40 \%$ plemenitih kovin, pri katalizatorju s $\mathrm{Cr} / \mathrm{Ni}$ trakom pa $0,74 \%$. Sintezni plin iz procesa taljenja je imel zelo nizko kurilno (kalorično) vrednost $\left(0,16 \mathrm{MJ} \mathrm{m}^{-3} \mathrm{oz} .0,24 \mathrm{MJ} \mathrm{m}^{-3}\right)$.

Ključne besede: odpadki, katalizator, kovine platinske skupine, plazemska tehnologija

\section{INTRODUCTION}

Plasma technology for the processing and disposal of different types of waste is becoming a subject of interest for many waste producers. This technology can be used to process, e.g., municipal waste, ash from thermal power stations, dangerous asbestos-based waste, etc. ${ }^{1-4}$ Plasma technology is also used when processing various kinds of industrial waste. ${ }^{5}$ Noble metals can be recovered from the metallic waste containing them. The recoverability of noble metals from slag is, for example, the subject of several papers. ${ }^{6-8}$ Noble metals can also be obtained from slag using chemical-based methods (e.g., leaching). The basis for this is the change of a given phase to the liquid phase. The extraction of $\mathrm{Cu}, \mathrm{Ag}, \mathrm{Au}$ and $\mathrm{Pd}$ by leaching in nitric acid is described by references. ${ }^{9-10}$ The yield of silver using this method is up to $87 \%$ and for copper, it is $98 \%$. The leaching of $\mathrm{Cu}$, $\mathrm{Zn}$ and $\mathrm{Pb}$ from $\mathrm{PCBs}$ using electro-generated chlorine in a hydrochloric acid solution is described in reference. ${ }^{11}$
A separate area in the use of plasma technologies is their involvement in the process of liquidating catalysers. In this area, results were obtained in various conditions using low-temperature thermal plasma. The by-products from processing this waste are always syngas and slag. ${ }^{12-15}$ The exploitation of the energy from syngas is the subject of paper ${ }^{16}$.

The article presents the results of experimental tests performed using an $80 \mathrm{kVA}$ plasma reactor to melt the autocatalysts. In addition to the autocatalysts, the plasma reactor enables the treatment of waste containing organic and plastic materials (textiles, wood, plastics, etc.) as well as non-combustible inert materials (glass, ceramics, etc.).

\section{DESCRIPTION OF CATALYSERS AND THEIR USE}

Used autocatalysts need to be regenerated and ultimately permanently disposed of. In the automotive industry, catalysts are used to reduce the three main components of harmful emissions in the exhaust gases of 
cars $-\mathrm{NO}_{\mathrm{x}}, \mathrm{CO}$ and unburnt hydrocarbons. This means that the aforesaid pollutants, with the help of the catalytic elements ( $\mathrm{Pt}, \mathrm{Pd}$ and $\mathrm{Rh}$ ) found on the walls of the catalyst carrier, are reduced or oxidized to less harmful chemical compounds.

Platinum and palladium take the predominant share in the removal of carbon monoxide and hydrocarbons; the rhodium additive is intended to improve the activity of an autocatalyst as reduction reactions lower the content of nitrogen oxide. First, platinum with rhodium catalyses the splitting of nitrogen oxides into nitrogen and oxygen, and then platinum with palladium catalyses the oxidation of carbon monoxide $(\mathrm{CO})$ and unburnt hydrocarbons with free oxygen into $\mathrm{CO}_{2}$ and water.

\section{MATERIAL, TECHNOLOGY, EXPERIMENTAL PART}

The autocatalysts were melted in the $80 \mathrm{kVA}$ plasma reactor with a dependent electric arc. The plasma-forming nitrogen gas was fed into the electric arc through a hollow graphite electrode where it was transformed into a plasma at a temperature of the order of $10^{3} \mathrm{~K}$. At such a temperature, independent of the partial pressure of oxygen, the organic and partly inorganic components of the waste are decomposed into simple compounds according to the chemical reaction in Equation (1): ${ }^{11}$

$$
\begin{aligned}
& \mathrm{C}_{\mathrm{a}} \mathrm{H}_{\mathrm{b}} \mathrm{O}_{\mathrm{c}} \mathrm{Cl}_{\mathrm{d}} \mathrm{S}_{\mathrm{e}} \mathrm{N}_{\mathrm{f}(\mathrm{s})}=x \mathrm{CO}_{(\mathrm{g})}+y \mathrm{H}_{2(\mathrm{~g})}+z \mathrm{~N}_{2(\mathrm{~g})}+w \mathrm{H}_{2} \mathrm{O}_{(\mathrm{g})}+ \\
& +v \mathrm{SO}_{2(\mathrm{~g})}+r \mathrm{HCl}_{(\mathrm{g})}
\end{aligned}
$$

The non-gaseous components of the waste are melted and two unmixable liquid phases are formed at the bottom of the plasma reactor - metallic alloy and slag. When melting autocatalysts, the gaseous product is a synthesis gas, which contains two combustible gases (hydrogen and carbon monoxide).

The plasma reactor ${ }^{15}$ was used to melt autocatalysts based on cordierite and autocatalysts based on $\mathrm{Cr} / \mathrm{Ni}$ strips.

A monolithic autocatalyst based on cordierite with a plastic structure (with a circular or elliptical cross-section) is made of ordinary cordierite with isomorphic iron $\left(2 \mathrm{FeO} \cdot 2 \mathrm{Al}_{2} \mathrm{O}_{3} \cdot 5 \mathrm{SiO}_{2}\right)$ or ordinary cordierite with isomorphic magnesium $\left(2 \mathrm{MgO} \cdot 2 \mathrm{Al}_{2} \mathrm{O}_{3} \cdot 5 \mathrm{SiO}_{2}\right)$. The cordierite is coated with the $\gamma-\mathrm{Al}_{2} \mathrm{O}_{3}$ gel film containing noble metals (platinum, palladium, iridium, rhodium). The average noble-metal amount in a catalyst is from $1.8 \mathrm{~g}$ to $2 \mathrm{~g}$ per $1 \mathrm{~kg}$ of ceramics with a $\mathrm{Pt}: \mathrm{Rh}$ ratio of $5: 1$. The housing of the autocatalyst, the closure carrier, is made of stainless steel with a high amount of nickel and chromium (Figure 1).

An autocatalyst on a $\mathrm{Cr} / \mathrm{Ni}$ strip is made from a chromium nickel strip wound into an $S$ shape, on which there is a coating consisting of a thin film of $\gamma-\mathrm{Al}_{2} \mathrm{O}_{3}$ containing $\mathrm{Pd}, \mathrm{Pt}, \mathrm{Rh}$ (Figure 2). Autocatalysts of this type are also supplied as monolithic carriers (Figure 3) in the form of the plastic of ordinary cordierite with isomorphic

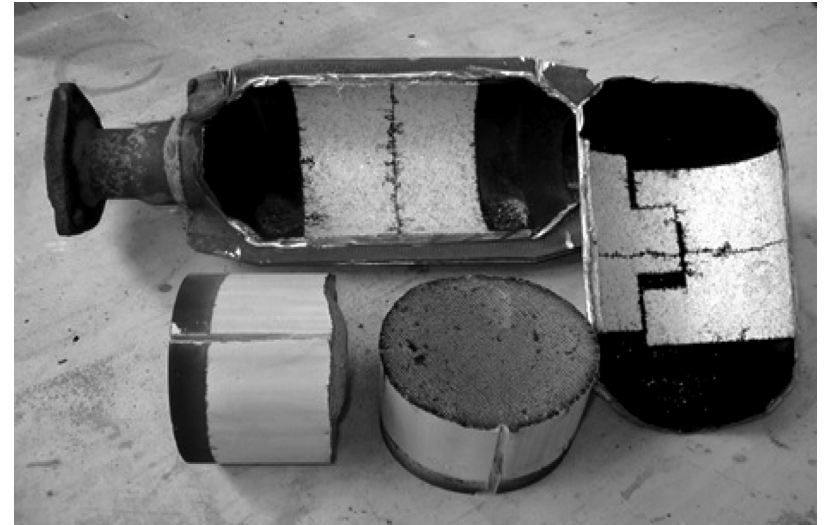

Figure 1: Casing and the cordierite insert ${ }^{11}$

$\mathrm{Fe}$ or $\mathrm{Mg}$. The monolithic carriers contain a thin film of $\gamma-\mathrm{Al}_{2} \mathrm{O}_{3}$ containing mainly $\mathrm{Pd}$.

Catalysers containing gold, silver, rhenium, rhodium, palladium, iridium or platinum have the waste code 16 08 01, while the ADR waste code is B 1150 .

Catalysts made of ordinary cordierite with isomorphic $\mathrm{Fe}$ or $\mathrm{Mg}$ were ground, before the experiment, to a granularity of $<8 \mathrm{~mm}$. The mix was of a grey colour. Autocatalysts on a $\mathrm{Cr} / \mathrm{Ni}$ strip were mechanically separated, before the experiment, from the catalytic layer of $\gamma-\mathrm{Al}_{2} \mathrm{O}_{3}$ containing $\mathrm{Pd}, \mathrm{Pt}$, $\mathrm{Rh}$ with a granularity $<1 \mathrm{~mm}$. The catalysts applied onto a $\mathrm{Cr} / \mathrm{Ni}$ strip resulted in dust of a yellow-to-cream colour.

Before the experimental tests, the samples were chemically analysed. The largest components of the cordierite-based autocatalyst were oxides $\mathrm{SiO}_{2}(37.03 \%$ mass fraction), $\mathrm{Al}_{2} \mathrm{O}_{3}$ (33.20\% mass fraction), $\mathrm{MgO}$ (9.80 \% mass fraction) and $\mathrm{Fe}_{2} \mathrm{O}_{3}(1.14 \%$ mass fraction). The autocatalyst based on $\mathrm{Cr} / \mathrm{Ni}$ strips included $\mathrm{Al}_{2} \mathrm{O}_{3}$ (55.67\% mass fraction), $\mathrm{CeO}_{2}$ (12.00\% mass fraction), $\mathrm{La}_{2} \mathrm{O}_{3}$ (6.87\% mass fraction), $\mathrm{SiO}_{2}(2.69 \%$ mass fraction) and $\mathrm{ZrO}_{2}(2.59 \%$ mass fraction). In this melting process, the slag-forming elements are considered to be $\mathrm{SiO}_{2}, \mathrm{Al}_{2} \mathrm{O}_{3}, \mathrm{Fe}_{2} \mathrm{O}_{3}$ and $\mathrm{MgO}$ or $\mathrm{CaO}$.

The fractions gained in this way, containing noble metals were subsequently melted in the plasma reactor with an addition of fluxes (quick lime) and the slag had a relatively low melting point (below $1400{ }^{\circ} \mathrm{C}$ ). At this temperature, the slag was saturated with a compound of

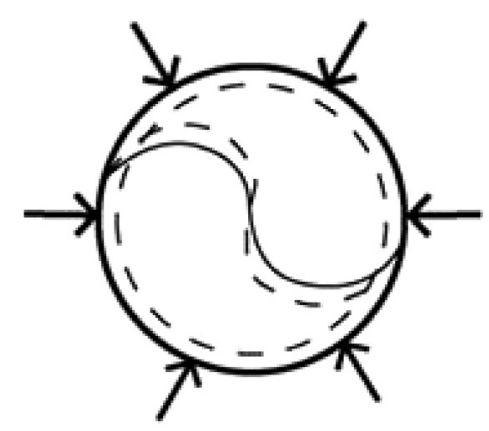

Figure 2: $\mathrm{S}$ twisting a $\mathrm{Cr} / \mathrm{Ni}$ strip into an $\mathrm{S}$ shape ${ }^{11}$ 
Table 1: Basic data on the input raw materials for the experiment

\begin{tabular}{|c|c|c|c|c|c|}
\hline & $\begin{array}{c}\text { Catalyser } \\
(\mathrm{kg})\end{array}$ & $\begin{array}{c}\text { Slag-forming } \\
\text { additive } \\
(\mathrm{kg})\end{array}$ & $\begin{array}{c}\text { Reduction agent } \\
(\mathrm{kg})\end{array}$ & $\begin{array}{c}\text { Time of experi- } \\
\text { ment } \\
(\mathrm{min})\end{array}$ & $\begin{array}{c}\text { Consumption of } \\
\text { el. energy } \\
(\mathrm{kWh})\end{array}$ \\
\hline cordierit & 313.5 & 47.1 & 77.5 & 1863 & 77.20 \\
\hline Cr/Ni strips & 90.0 & 77.5 & 77.5 & 1175 & 73.85 \\
\hline
\end{tabular}

*volume of gas media at a pressure of $101.325 \mathrm{kPa}$ and temperature of $25^{\circ} \mathrm{C}$

Table 2: Masses of alloys and their chemical compositions

\begin{tabular}{|c|c|c|c|c|c|c|}
\hline & Fe+PGM alloy & \multicolumn{4}{|c|}{ Chemical composition } \\
\cline { 3 - 6 } & $(\mathrm{kg})$ & $\mathrm{Pt}\left(\mathrm{g} \cdot \mathrm{kg}^{-1}\right)$ & $\mathrm{Pd}\left(\mathrm{g} \cdot \mathrm{kg}^{-1}\right)$ & $\mathrm{Rh}\left(\mathrm{g} \cdot \mathrm{kg}^{-1}\right)$ & $\mathrm{Fe}-\mathrm{C}(\%)$ & $\mathrm{C}$ in Fe $(\%)$ \\
\hline cordierit & 16.50 & 9.47 & 22.33 & 6.18 & 96.04 & 3.35 \\
\hline Cr/Ni strips & 18.00 & 5.095 & 16.74 & 3.28 & 97.21 \\
\hline
\end{tabular}

Table 3: Masses of slags and their chemical compositions

\begin{tabular}{|c|c|c|c|c|c|c|c|}
\hline \multirow{2}{*}{ catalyser } & \multirow{2}{*}{$\begin{array}{l}\text { slag } \\
(\mathrm{kg})\end{array}$} & \multicolumn{5}{|c|}{$(w / \%)$} & \multirow{2}{*}{$\begin{array}{c}\sum(\mathrm{g}) \\
\text { PGM }\end{array}$} \\
\hline & & $\mathrm{CaO}$ & $\mathrm{MgO}$ & $\mathrm{SiO}_{2}$ & $\mathrm{Al}_{2} \mathrm{O}_{3}$ & $\mathrm{Fe}+\mathrm{PGM}$ & \\
\hline cordierite & 353.50 & 16.77 & 12.47 & 30.08 & 37.85 & 1.33 & 2.12 \\
\hline $\mathrm{Cr} / \mathrm{Ni}$ strips & 187.30 & 42.00 & 0.33 & 3.86 & 47.37 & 1.02 & 1.18 \\
\hline
\end{tabular}

the $x \mathrm{CaO} \cdot y \mathrm{Al}_{2} \mathrm{O}_{3}$ type or pure aluminium oxide to prevent corrosion of the lining in the plasma reactor with a high $\mathrm{Al}_{2} \mathrm{O}_{3}$ content. When melting the autocatalysts, in addition to the flux in the plasma reactor, $15 \mathrm{~kg}$ of grey cast iron was added as a collector of noble metals in the form of cast-iron castings (for each melt). The composition of the charge for both autocatalysts is presented in Table 1. The table also shows the duration of the experiment, the average electricity consumption and the consumption of the nitrogen plasma-forming gas.

The amounts of the noble metals of interest and the chemical compositions of the alloys from the melting and gasification process for the two autocatalysts are given in Table 2. The chemical analysis shows that the alloy of grey cast iron and platinum-group metals is a metal collector. The Fe+PGM alloy is the raw material for the hydro-metallurgical production of the noble metals Pt, Pd and Rh.

The chemical composition of the slag from the melting and gasification of these autocatalysts is summarized

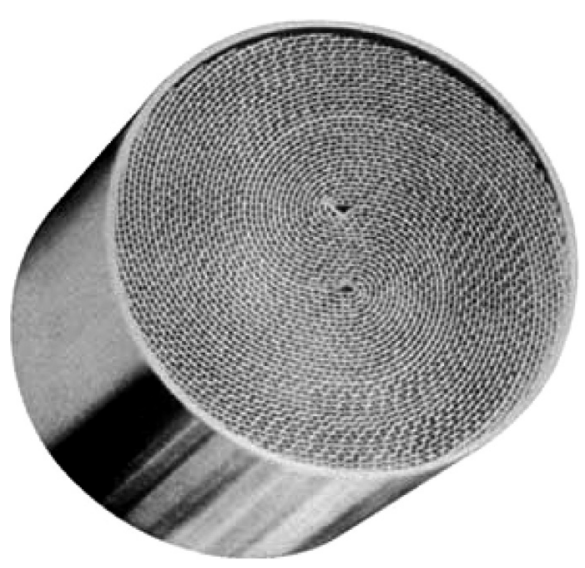

Figure 3: Carrier of the catalyser ${ }^{11}$ in Table 3. The table shows that all the elements with a high affinity to oxygen, such as $\mathrm{Al}, \mathrm{Si}, \mathrm{Mg}$ and $\mathrm{Ca}$, were concentrated in the slag.

In the slag, there were also non-sedimentary particles of Fe-containing noble metals, which represent mechanical losses of these metals in the slag (Figure 4). It was therefore necessary to recycle the slag by crushing, grinding and with the subsequent magnetic separation.

The results of the leaching tests for slag confirmed that this slag is inert and non-leachable. This means that no undesirable metals or elements leach from the slag and, therefore, it can be deposited in a landfill as other waste. This slag can also be used in civil engineering as a backfill or drainage material. The slag is also suitable for the production of glass fibres used in the production of heat- and electrical-insulation materials, as well as in the metallurgy of iron and steel.

The gas generated in the melting process was removed from the plasma reactor through a cyclone

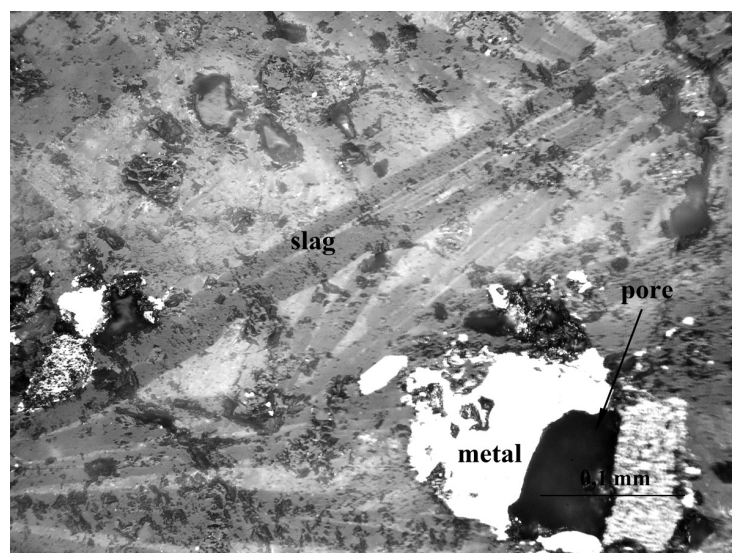

Figure 4: Macrophotography of mechanically removed particles of iron with $\mathrm{Pt}, \mathrm{Pd}$ and $\mathrm{Rh}$ in the slag matrix 


\section{M. ČARNOGURSKÁ et al.: HIGH-TEMPERATURE PROCESSING AND RECOVERY OF AUTOCATALYSTS}

separator where most of the mechanically removed ash was trapped. The chemical composition of the fly ash captured mainly in the cyclone separator, and subsequently in the other filtration devices, is summarized in Table 4. The chemical analysis shows that the ash (apart from the oxides of $\mathrm{CaO}, \mathrm{SiO}_{2}, \mathrm{MgO}, \mathrm{Al}_{2} \mathrm{O}_{3}$ mechanically removed from the batch and the unreacted carbon added to the batch) also contained condensed vapour of Fe. The fly ash can be recycled without any major problems, thus increasing the share of the precious metals extracted from the waste being processed.

Table 4: Mass of fly ash and its chemical analysis

\begin{tabular}{|c|c|c|c|c|c|c|c|c|}
\hline catalyser & $\begin{array}{c}\mathrm{Fly} \\
\text { ash } \\
\end{array}$ & $(v / \%)$ & \multicolumn{6}{|c|}{$\Sigma(\mathrm{g})$} \\
\cline { 3 - 10 } & $\mathrm{CaO}$ & $\mathrm{MgO}$ & $\mathrm{SiO}_{2}$ & $\mathrm{Al}_{2} \mathrm{O}_{3}$ & $\mathrm{C}_{\text {celk. }}$ & $\mathrm{Fe}_{\text {celk. }}$ & PGM \\
\hline cordierit & 5.7 & 16.50 & 6.55 & 18.39 & 13.34 & 2.47 & 15.13 & 2.5 \\
\hline $\begin{array}{c}\mathrm{Cr} / \mathrm{Ni} \\
\text { pásky }\end{array}$ & 5.9 & 28.05 & 3.05 & 7.92 & 12.00 & 2.96 & 1.40 & 3.4 \\
\hline
\end{tabular}

\section{DISCUSSION OF THE RESULTS OBTAINED}

From the point of view of the material and energy utilization of the waste, the plasma melting and gasification of autocatalysts in the $80 \mathrm{kVA}$ plasma reactor can be evaluated as follows.

Besides the alloy and slag, a by-product of the melting of autocatalysts is synthesis gas. It results from the reduction of the catalysts and the high-temperature pyrolytic decomposition of the organic portions of feedstocks. The gas was removed from the plasma reactor via a cyclone separator. Most of the mechanically removed ash was captured here. Subsequently, the synthesis gas was cooled from $1500-1600{ }^{\circ} \mathrm{C}$ to $160-170{ }^{\circ} \mathrm{C}$ in a hydrocyclone and then microparticles were collected in a sleeve filter. In the next step, the acidic constituents of the synthesis gas were neutralized in a countercurrent absorption column $(\mathrm{pH}=9$ of the neutralizing solution of $\mathrm{NaOH}$ ). From the absorption column, the synthesis gas was fed into a system of coolers where, in the first step, it was cooled below the dew point of $60{ }^{\circ} \mathrm{C}$ to

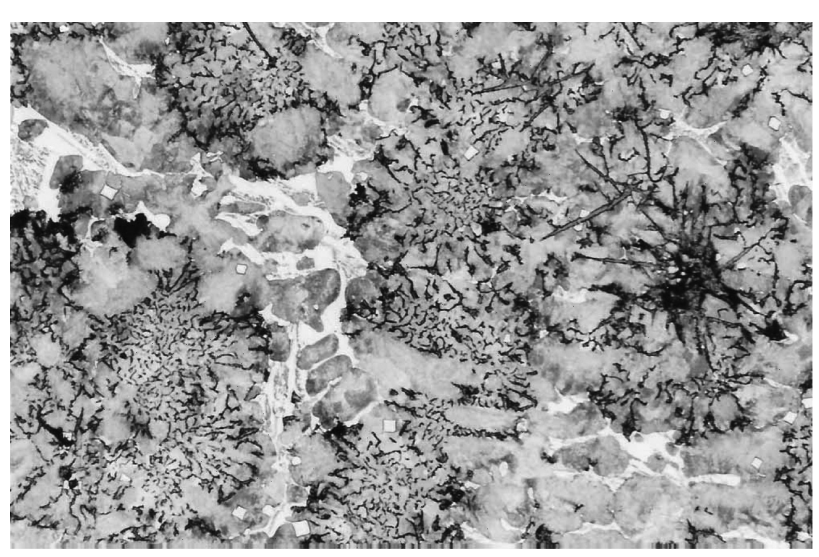

Figure 5: Macrophotography of the slag matrix with a melting autocatalyst on a $\mathrm{Cr} / \mathrm{Ni}$ strip precipitate the moisture, with which the synthesis gas was saturated after the cooling in the hydrocyclone and the neutralization process. After the cooling, the gas was heated above the dew point and then burnt in a cogeneration unit with a CAPSTONE C65 microturbine.

The concentration of the main synthesis-gas components was continuously measured with a chromatograph during the melting. The results of the measurement of the proportions of $\mathrm{H}_{2}, \mathrm{CO}$ and $\mathrm{CO}_{2}$ in the gas, resulting from the melting of the cordierite autocatalyst, is shown in Figure 6. The chromatograph also searched for methane but it was not found in the synthesis gas. Of flammable gases, the syngas contained only hydrogen and carbon monoxide. The proportion of $\mathrm{H}_{2}$ fluctuated between $0.79 \%$ and $0.98 \%$ (an average of $0.89 \%$ ), and the CO content ranged from $1.04 \%$ to $1.27 \%$ (an average of $1.15 \%$ ).

The average concentrations of the major components of the synthesis gas from the continuous chromatographic measurement of $\mathrm{CO}, \mathrm{CO}_{2}, \mathrm{H}_{2}$ and $\mathrm{N}_{2}$ during the melting of both types of catalysers are summarised in Table 5.

Table 5: Average composition of syngas

\begin{tabular}{|c|c|c|c|c|c|}
\hline \multirow{2}{*}{ catalyser } & \multirow{2}{*}{$\begin{array}{c}\text { syngas } \\
\left(\mathrm{m}^{3} \cdot \mathrm{h}^{-1}\right)\end{array}$} & \multicolumn{4}{|c|}{$(v / \%)$} \\
\cline { 3 - 6 } & $\mathrm{H}_{2}$ & $\mathrm{CO}$ & $\mathrm{CO}_{2}$ & $\mathrm{~N}_{2}$ \\
\hline cordierite & 15.77 & 0.89 & 1.14 & 0.40 & 97.57 \\
\hline Cr/Ni strips & 14.91 & 0.60 & 0.74 & 0.28 & 98.38 \\
\hline
\end{tabular}

*volume of gas media at a pressure of $101.325 \mathrm{kPa}$ and temperature of $25^{\circ} \mathrm{C}$

Because of the small proportion of flammable gases, the lower heating value (LHV) of the synthesis gas was very low. When processing the cordierite catalyst, the average LHV was around $0.24 \mathrm{MJ} \mathrm{m}^{-3}$, and only $0.16 \mathrm{MJ} \mathrm{m}^{-3}$ when melting the $\mathrm{Cr} / \mathrm{Ni}$-based catalyst. The energy benefit of the synthesis gas with the given LHV was negligible in the energy-production process. However, it is appropriate to use synthesis gas in the cogeneration unit.

A division of the platinum-group metals obtained from the alloy, slag and fly ash is shown in Table 6. It is

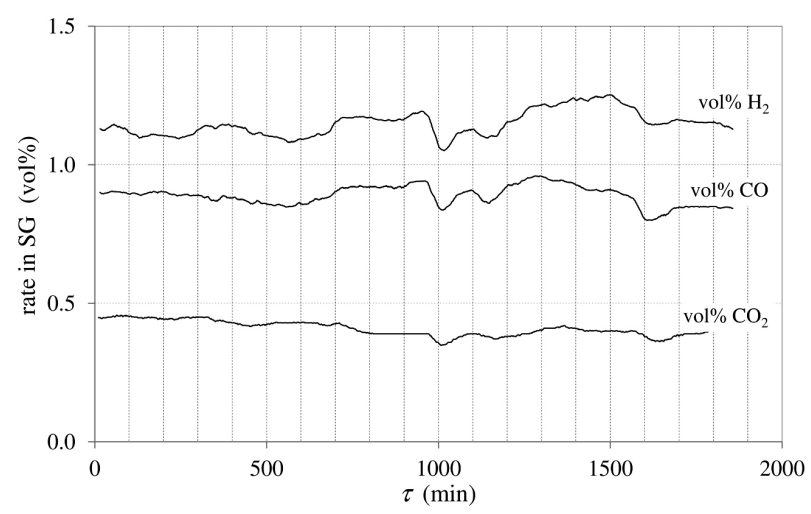

Figure 6: Contents of $\mathrm{H}_{2}, \mathrm{CO}$ and $\mathrm{CO}_{2}$ in the syngas when melting the cordierite autocatalyst 
obvious that minimum amounts of these metals passed into the slag and fly ash. For the $\mathrm{Cr} / \mathrm{Ni}$-strip-based autocatalyst, it was $1.00 \%$ and only $0.74 \%$ for the cordierite autocatalyst.

Table 6: Fractions of the total PGMs recovered with melt products

\begin{tabular}{|c|c|c|c|}
\hline \multirow{2}{*}{ catalyser } & alloy & slag & fly ash \\
\cline { 2 - 4 } & \multicolumn{3}{|c|}{ \% PGM } \\
\hline cordierite & 99.27 & 0.33 & 0.40 \\
\hline Cr/Ni strips & 99.00 & 0.26 & 0.74 \\
\hline
\end{tabular}

The diffusion of metals into the plasma-reactor lining did not occur because the entire volume of the liquid phases (metal and slag) was kept in the graphite part of the reactor. This resulted in a minimum loss of the metals in the lining.

Cast iron was used as the collector of the noble metals. It is affordable, has high sorption capabilities with regard to platinum-group metals and magnetic properties that allow mechanically removed metal particles in slag to be separated. This means that the debris from the experimental melts were magnetically separated after grinding and milling, thereby increasing the yield of the metals of interest ( $\mathrm{Pt}, \mathrm{Pd}$ and $\mathrm{Rh}$ in $\mathrm{Fe}$ ).

\section{CONCLUSION}

The liquidation of used autocatalysts in a plasma reactor can clearly reduce the environmental burden. Three major products can be obtained from the melting process: Fe+PGM alloy, slag and synthesis gas. The alloy of grey cast iron and platinum-group metals from the process of melting is the metal collector. The alloy is a raw material suitable for hydro-metallurgical production of noble metals $\mathrm{Pt}, \mathrm{Pd}$ and $\mathrm{Rh}$.

The slag with non-sedimentary Fe particles, which also contain noble metals, needs to be recycled to reduce the mechanical loss of metals. After crushing and grinding the slag, the iron from the platinum-group metals can be separated using magnets. The slag can also be used in ferrous metallurgy and civil engineering.

The synthesis gas from the melting of both types of autocatalysts has energy parameters that enable its use in the production of heat and electricity in a cogeneration unit. The share of the synthesis gas of the average natural-gas consumption is less than $0.5 \%$.

An accompanying feature of melting autocatalysts is fly ash in the synthesis gas that, in addition to the $\mathrm{CaO}$, $\mathrm{MgO}, \mathrm{SiO}_{2}$ and $\mathrm{Al}_{2} \mathrm{O}_{3}$ oxides removed from the batch, also contains condensed vapour of Fe. It is therefore advisable to recycle fly ash, thereby additionally increasing the return of the metals of interest from the process of melting the catalysts.

Based on the results obtained by melting the autocatalysts, it can be stated that this waste can be further processed with the plasma technology into a product of an inert nature and the resulting melt products. This means that the presented elimination of the analysed waste by plasma melting is a waste-free BAT technology.

Previous experimental studies confirm that the prospective areas of use of plasma technologies will be the recycling and disposal of hazardous waste and low-level radioactive materials, and the refining of materials to high purity.

\section{Acknowledgements}

This research was realised with the support of the KEGA Grant Agency, nos. 003TUKE-4/2016 and SP2017/37-FMMI VŠB TUO.

\section{REFERENCES}

${ }^{1}$ J. Vlček, M. Velička, D. Jančar, J. Burda, V. Blahůšková, Modelling of thermal processes at waste incineration, Energy Sources, Part A: Recovery, Utilization and Environmental Effects, 38 (2016) 23, 3527-3533, doi:10.1080/15567036.2016.1161680

${ }^{2}$ M. Lázár, M. Čarnogurská, T. Brestovič, N. Jasminská, L. Kmet’ová, L. Kapustová, T. Jezný, High-Temperature Processing of AsbestosCement Roofing Material in a Plasma Reactor, Pol. J. Environ. Stud., 25 (2016) 5, 2027-2033, doi:10.15244/pjoes/62959

${ }^{3}$ M. Lázár, M. Čarnogurská, M. Lengyelová, J. Korba, High-temperature gasification of RDF wastes and melting of fly ash obtained from the incineration of municipal wastes, Acta Polytechnica, 55 (2015) 1, 1-6, doi:10.14311/AP.2015.55.0001

${ }^{4}$ M. Mabrouk, M. Marchand, J. M. Baronnet, F. Lemont, Trichloroethylene Combustion in a Submerged Thermal Plasma: Results and Chemical Kinetics Model, Plasma Chem. Plasma Process., 36 (2016), 1085-1110, doi:10.1007/s11090-016-9693-6

${ }^{5}$ B. M. Ludvigsson, S. R. Larsson, Anode slimes treatment: The boliden experience, JOM, 55 (2003) 4, 41-44, doi:10.1007/s11837003-0087-x

${ }^{6}$ H. E. Hilliard, B. W. Dunning, D. A. Kramer, D. M. Soboroff, Hydrometallurgical treatment of electronic scrap to recover gold and silver, Bureau of Mines Report of Investigations, RI-8940 (1985), $1-20$

${ }^{7}$ H. Dong, J. Zhao, J. CHen, Y. Wu, B. Li, Recovery of platinum group metals from spent catalyst: A review, International Journal of Mineral Processing, 145 (2015), 108-113, doi:10.1016/j.minpro. 2015.06.009

${ }^{8}$ M. K. Jha, J. CH. Lee, M. S. Kim, J. Jeong, B. S. Kim, V. Kumar, Hydrometallurgical recovery /recycling of platinum by the leaching of spent catalysts: A review, Hydrometalurgy 133 (2013) 23-32, doi:10.1016/j.hydromet.2012.11.012

${ }^{9}$ E. Y. Kim, M. S. Kim, J. CH. Lee, J. Jeong, B. D. Pandey, Leaching kinetics of copper from waste printed circuit boards by electrogenerated chlorine in $\mathrm{HCl}$ solution, Hydrometalurgy, 107 (2011) 3-4, 124-132, doi:10.1016/j.hydromet.2011.02.009

${ }^{10}$ Z. Ping, F. Z. Yun, L. Jie, L. Qiang, Q. Guangren, Z. Ming, Enhancement of leaching copper by electro-oxidation from metal powders of waste printed circuit board, Journal of Hazardous Materials, 166 (2009) 2-3, 746-750, doi:10.1016/j.jhazmat.2008. 11.129

${ }^{11}$ M. Bousa, F. Vesely, P. Kurilla, J. Kondas, PGM Catalysts Treatment in Plasma Heated Reactors, $32^{\text {nd }}$ International precious metals conference, Phoenix, Arizona, USA, 1 (2008), 279-291

${ }^{12}$ D. L. Canham, V. G. Aurich, Recovery of Metals from Spent Catalysts in a DC Plasma Furnace, EMC '91: Non-Ferrous Metallurgy Present and Future, Springer Link, (1991), 241-247, doi:10.1007/ 978-94-011-3684-6_24 
${ }^{13}$ J. Cui, L. Zhang, Metallurgical recovery of metals from electronic waste: A review, Journal of Hazardous Materials. 158 (2008) 2-3, 228-256, doi:10.1016/j.jhazmat.2008.02.001

${ }^{14}$ M. Čarnogurská, M. Př́íhoda, M. Lázár, P. Kurilla, Pyrometallurgical treatment of silver-containing catalysts, Mater. Tehnol., 52 (2018) 2 , $133-138$

${ }^{15}$ M. Čarnogurská, M. Lázár, M. Příhoda, B. Skočilasová, P. Kurilla, J. Marek, High-temperature Processing and Recovery of $\mathrm{Cu}$ Catalyst Promoter, Manufacturing Technology, 15 (2017) 6, accepted

${ }^{16}$ J. Jandačka, R. Nosek, M. Holubčík, Effect of selected additives to properties of wood pellets and their production, Acta Facultatis Xylologiae, 53 (2011) 2, 85-91 